\title{
Theatrical Marginalia: Pierre Baillot and the Prototype of the Modern Performer
}

\author{
Fabio Morabito
}

In a history documenting the accomplishments of forward-looking individuals, facilitators of yet-to-be-established cultural orders, the credit for ushering the 'age of Beethoven' in Paris could go to the violinist Pierre Baillot. The series of chamber music concerts he led from 1814 to 1840 has long been recognised as a major contribution to the diffusion of a repertory that, up until then, was little known outside professional circles: the string quartets and quintets of Boccherini and Mozart and the quartets of Haydn and Beethoven. ${ }^{1}$ Baillot's concert series was the first of its kind in Paris, championing chamber instrumental music for a selected audience of paying attendees (including Baillot's friends among the upper middle class and aristocracy, many of whom were themselves accomplished amateur musicians). ${ }^{2}$ James H. Johnson among others has discussed this concert venture as key in accustoming Parisians to non-descriptive instrumental works (as opposed to, for instance, the evocative prompts in the titles of Couperin's or Rameau's music) and hence altogether to a new paradigm of listening emerging at the time. ${ }^{3}$ Indeed, the explosion in Paris of 'Beethoven

\footnotetext{
${ }^{1}$ In early nineteenth-century Paris, string quartets by Haydn and Mozart were generally regarded as being difficult to play. Parisian salons favoured the more manifestly dialogic style of composers writing along the lines of the quatuor concertant (such as Nicolas Dalayrac, François-Joseph Gossec, Jean-Baptiste Davaux and Giuseppe Maria Cambini). However, string quartets of greater length and featuring a richer variety of textures were regularly enjoyed in the city among connoisseurs and professional musicians; see for instance Eugène Sauzay, Haydn, Mozart, Beethoven, étude sur le quatuor (Paris, 1861), 24; Jean Mongrédien, French music from Enlightenment to Romanticism: 1789-1830 (Portland, 1996), 267, 293.

2 Joël-Marie Fauquet lists all the works that were performed in Baillot's chamber soirées, concert by concert, for about twenty-five years; see Joël-Marie Fauquet, Les sociétés de musique de chambre à Paris de la Restauration à 1870, (Paris, 1986), 20-112; James H. Johnson, Listening in Paris: A Cultural History (Berkeley, 1995$), 204$.

${ }^{3}$ James H. Johnson, 'Beethoven and the Birth of Romantic Musical Experience in France', 19th-Century Music, 15/1 (1991), 23, 32. Reiterating Johnson's claim of a transformation of tastes during the 1820s, Markella Vandoros discusses Baillot as a 'patient innovator', who devised his programmes to get the public progressively
} 
fever' from the late 1820s is often explained in relation to a general shift from perceiving music as a rhetorical art (as if the audience was being told a story by the performer-orator, or witnessing a staged conversation among the performers-actors) to understanding music as an object of contemplation, calling for a silent immersion in purely musical depths. ${ }^{4}$ The broader revolution Baillot is credited with having facilitated, in this respect, is one that reshaped the tasks of music-makers and consumers around a new status of music per se. As far as today's common conceptualisations of the act of listening to Western art music are concerned - and it is also true of composing and performing - we are, in the words of Mark Evan Bonds, still 'in the age of Beethoven' 5

The image of Baillot as one of the Parisian precursors of this 'Beethoven Revolution' is grounded especially in the programmes of his concert series. The regularity with which the ensemble played Boccherini, Haydn, Mozart and Beethoven - each concert typically including one work by each of them - underscores the wish to establish a canon of great composers and masterworks in this genre, which in Paris at the time was generally referred to as 'musique de quatuors' (equally including music for string trio, quartet, quintet, sextet, etc.). ${ }^{6}$ Moving from one quartet or quintet to the next, Baillot's ensemble entertained its audience for the whole two-and-half-hours performance. This was still unusual in 1814, and for most of the 1820s, when the typical concert format mixed symphonies with operatic

used to Beethoven; Vandoros, 'Pierre Baillot (1771-1842): Institutions, Values and Identity' (PhD diss., King's College London, 2015), 49, 161-62, 183;

${ }^{4}$ Johnson, 'Beethoven and the Birth of Romantic Musical Experience in France', 23, 30. This 'Beethoven Revolution' is usually discussed in connections with the founding in 1828 of the Société des Concerts, an orchestra of Conservatoire students, alumni and professors led by the violin instructor François-Antoine Habeneck, himself a former pupil of Baillot at the Conservatoire. The orchestra gained an almost immediate reputation for its high standard performances of Beethoven's symphonies, which remained the centrepiece of the Société's programmes for the next decade; see D. Kern Holoman, The Société des Concerts du Conservatoire, 1828-1967 (Berkeley, 2004), 60. Several studies have reacted to Johnson's revolutionary stance discussing various attitudes in Paris at the time resisting the 'simple teleology' of musical orations or conversations being suddenly 'hushed into transfixed worship' of purely musical matters; Cormac Newark, 'Not Listening in Paris: Critical and Fictional Lapses of Attention at the Opera', in Katharine Ellis, Phyllis Weliver (ed.) Words and Notes in the Long Nineteenth Century (Woodbridge, 2013), 35-53. Mark Evan Bonds stresses how Beethoven's music did not cause 'a revolution in listening': his music was, however, 'the direct and immediate beneficiary of this new outlook', Mark Evan Bonds, Music as Thought: Listening to the Symphony in the Age of Beethoven (Princeton, 2006), 28.

${ }^{5}$ Mark Evan Bonds, 'Rhetoric vs. Truth: Listening to Haydn in the Age of Beethoven', in Tom Beghin, Sander M. Goldberg (ed.), Haydn and the Performance of Rhetoric (Chicago, 2007), 112, 128. The new emphasis on composers in discourses and pedagogical writings about performance in the early nineteenth century is discussed in Mary Hunter, "To Play as if from the Soul of the Composer": The Idea of the Performer in Early Romantic Aesthetics', Journal of American Musicological Society, 58 (2005), 357-398.

${ }^{6}$ Sauzay, Haydn, Mozart, Beethoven, étude sur le quatuor, 1; Fauquet, Les sociétés de musique de chambre à Paris de la Restauration à 1870, 20-112; see also Lydia Goehr, The Imaginary Museum of Musical Works: An Essay in the Philosophy of Music (2nd edn, New York, 2007), 206-242. 
extracts, instrumental solos, chamber music or characteristic pieces. ${ }^{7}$ Detecting this sober diet of string quartets and quintets in Baillot's soirées, scholars have typically projected an aura of seriousness on the series, as if the concerts were less about providing an engaging variety for the audience, and more about exhibiting works of art, inviting exegesis. ${ }^{8}$ Baillot's programmes, in this light, seem to place musical works centre stage: an attitude that would become the norm for concert series such as that of Baillot's pupil Jean-Paul Maurin, which was dedicated exclusively (at least at its inception in 1852) to the late Beethoven quartets and to 'uncovering their enigmas', as an article announcing the series put it. ${ }^{9}$

If his programmes seem to inscribe Baillot in a clear link with the generation of his pupils, his writings offer a different perspective. Mary Hunter has convincingly traced in Baillot's and contemporaries' treatises an early nineteenth-century discourse about performance, one distinct from later approaches. Although the composer's work was increasingly presented as self-standing and 'complete' on the page, the shift was a highly contested one. Dissenting voices of pedagogues such as Baillot maintained that in bringing the score to life 'the most desirable performance projected the illusion of creating the music anew', blurring the line between creator and re-creator. ${ }^{10}$ Extending the chronological purview of aesthetic and pedagogical writings, Mine Doğantan-Dack argues that the belief that music did not reside in the score but in the act of performance remained prominent throughout the nineteenth century, in essence as a parallel discourse to Lydia Goehr's archaeology of Werktreue. ${ }^{11}$ Developing Hunter's approach, in this article I suggest that Baillot's case provides an opportunity to see the two stances not as separate ideologies of the musical nineteenth century, championed by opposing factions, but rather as intertwined and equally relevant impulses within the same discourse, practices and among the same historical actors. I posit that the repertoire focus of Baillot's concert series and the absence of vocal music were not necessarily the series' most important characteristics, as if the enterprise was about championing this exclusion and the shift from a speech-like to speechless paradigm of

\footnotetext{
${ }^{7}$ William Weber, The Great Transformation of Musical Taste: Concert Programming from Haydn to Brahms (Cambridge, 2008), 35, 85-88.

${ }^{8}$ Fauquet, Les sociétés de musique de chambre à Paris de la Restauration à 1870, 68; Vandoros, 'Pierre Baillot (1771-1842): Institution, Values and Identity', 41-77.

${ }^{9}$ La France Musicale, 48 (28 Nov 1852), 390. Maurin's concert series was tellingly called 'Société des derniers quatuors de Beethoven'; see Fauquet, Les sociétés de musique de chambre à Paris de la Restauration à 1870, 125-36.

${ }^{10}$ Hunter, 'To Play as if from the Soul of the Composer', 363.

${ }^{11}$ Mine Doğantan-Dack, "Phrasing - the Very Life of Music": Performing the Music and Nineteenth-Century Performance Theory', Nineteenth-Century Music Review, 9/1 (2012), 7-20.
} 
performing and listening. In his pedagogical vision, Baillot entrusted the modern performer to become a champion of the new musical museum precisely by virtue of refined rhetorical skills and persuasive impersonations.

Challenging histories of a broad shift from the culture of rhetoric to the triumph of 'absolute music' is in itself familiar in recent musicological commentary. Nicholas Mathew, for instance, has uncovered how the topical character of Beethoven symphonies (and its cultural-political resonances at the time of their first performances) can best be understood as an 'orchestral transmutation' of the tradition of grand choral singing associated with Handel's oratorios. ${ }^{12}$ Similarly, Benjamin Walton has reassessed the Parisian success of Beethoven in the late 1820s suggesting that, to Parisian ears, his symphonies sounded like recent operas by Rossini. ${ }^{13}$ Revisiting the Dahlhausian concept of a 'crystallisation of the rift' between two rival cultures of music, Mathew and Walton invite us to appreciate overlooked continuities between vocal and instrumental realms in the early nineteenth century, in the process highlighting how Dahlhaus tends to conflate this earlier period with mid-nineteenth-century aesthetics and, especially, with later notions of absolute music. ${ }^{14}$ It is not unexpected, then, that the 'purely musical' reputation of Baillot's concert series should come into question. My approach in pursuing this objective has been shaped by an unusual (hence long unexplored) archive connected to the activities of Baillot's ensemble. Not only have the programmes of their concerts survived, but so has some of the sheet music: the parts from which the ensemble performed. What is more, several items from the chamber music library previously owned by Baillot and evidently used by his ensemble contain a wealth of handwritten annotations. These are mainly pencil marginalia that the musicians (and particularly Baillot in his first violin part) added in preparation for their performances, ranging from fingerings and bowings to articulation markings and ensemble colours. ${ }^{15}$

\footnotetext{
${ }^{12}$ Nicholas Mathew, 'Beethoven's Political Music, the Handelian Sublime, and the Aesthetics of Prostration, 19th-Century Music, 33/2 (2009), 110-150.

${ }^{13}$ Benjamin Walton, Rossini in Restoration Paris: the Sound of Modern Life (Cambridge, 2007), 175.

${ }^{14}$ Carl Dahlhaus, Die Musik des 19. Jahrhunderts [1980] reprint. in Dahlhaus, Gesammelte Schriften in 10 Bänden, 5, ed. Herman Danuser (Laaber, 2003); translated as Nineteenth-Century Music, trans. J. Bradford Robinson (Berkeley, 1989), 8-15; Nicholas Mathew, "Achieved is the Glorious Work": The Creation and the Choral Work Concept', in Mary Hunter, Richard Will (ed.), Engaging Haydn: Context, Culture, and Criticism (Cambridge, 2012), 126; Nicholas Mathew, Benjamin Walton (ed.), The Invention of Beethoven and Rossini: Historiography, Analysis, Criticism (Cambridge, 2013); see also John Neubauer, The Persistence of Voice: Instrumental Music and Romantic Orality (Leiden, 2017).

${ }^{15}$ Items from Pierre Baillot's personal and music library, including the annotated parts, are preserved at the Bibliothèque nationale de France in Paris, particularly in the Fonds Lainé, and in the private collection of Daniel Lainé (one of Baillot's living heirs). Baillot's annotated part of Beethoven Violin Concerto Op. 61 is available online in Ressources numériques autour de la musique romantique française, http://bruzanemediabase.com/Fonds-d-archives/Fonds-Baillot. The sample of annotated chamber music parts
} 
In exploring the marginalia that Baillot and his affiliates left on string quartets and quintets by Boccherini, Beethoven and others, there is a potential to add a further perspective in telling the story of these chamber music concerts. Mine is not an attempt to recover the performers' style of playing or how a specific passage might have sounded in their rendering. Yet the annotations can be read as snapshots of how these performers approached the musical text more generally: how they understood their role in bringing the score to life. I propose to reassess these musicians' writings about the task of the performer against traces of their performances. Inspecting the annotations allows us to gain an insider's perspective, and to ask how or to what extent these musicians may have pursued such aims in practice. Complicit their ephemerality, and the often fragmentary sources documenting such processes, the actions and agency of performers have been marginalised in traditional narratives of the history of music. Much in the spirit of Carlo Ginzburg's dictum to make gaps in the sources part of the historical account, I am interested in both what these performers did and did not annotate: the fragmentariness of these traces is itself telling of the relationship between the musicians' systems of belief, values and representations. ${ }^{16}$ Beyond patching together the annotations for a specific performance (whether legato here or staccato there), I have chosen to explore the values these annotated parts stood for throughout the period in which Baillot's ensemble used them, shedding light on how the musicians saw themselves within the broader cultural transformations that affected the way music was notated and marketed in these decades. In so doing, my focus is on the so called 'longue-durée' trends in the history of musicians and scores: the slowly evolving structures that shaped the modern relationship between musical texts and individuals handling them. ${ }^{17}$

that constituted the basis for the present study is available online as part of the AHRC Project 'Collection of Historical Annotated String Editions' (CHASE), University of Huddersfield, http://mhm.hud.ac.uk/chase/. ${ }^{16}$ See Carlo Ginzburg, John Tedeschi and Anne C. Tedeschi, 'Microhistory: Two or Three Things that I Know about It', Critical Inquiry, 20/1 (1993), 10-35. Whenever available, I provide the relevant chronological markers, but often we have no information (or no single date) for when a given part was purchased, when it was handled and annotated, perhaps on several occasions through the years. As is to be expected, the surviving annotated parts find only occasional correspondences with the programmes of Baillot's concert series. It is easy to imagine that some pieces were rehearsed and annotated by the ensemble but were then not included in a soirée. Similarly, the programmes show that some works were featured on several occasions, but it is also likely that the ensemble played many of them outside the subscription series for which Baillot kept the documentation that has survived. For these reasons, I have not attempted to position each annotated part in a strict chronological sequence or chart the ensemble's performances over the years.

${ }^{17}$ See, for instance, the essays collected in Kate van Orden (ed.), Music and the Cultures of Print (New York, 2000), particularly Roger Chartier, 'Afterword: Music in Print', 325-41; and Chartier, The Order of Books, trans. Lydia Cochrane (Stanford, 1994); Kate van Orden, Materialities: Books, Readers, and the Chanson in 16th-Century Europe (Oxford, 2015). 
By interweaving evidence from the ensemble's annotations with Parisian writings on string quartet performance in these decades (such as those by Baillot himself, by Bernard Germain de Lacépède, Jérôme-Joseph de Momigny, Castil-Blaze, and François-Joseph Fétis among others), my aim is to reconcile Baillot with the broader performance culture with which he was imbued, and avoid seeing him as a promoter against the grain of a future cultural order. In particular, I trace the persistence throughout his career of a discourse and approach to instrumental performance through the lens of theatricality, showing essential continuities with the rhetorical and speech-like paradigm. Parisian commentators in these decades conceptualised the persuasiveness of instrumental concerts primarily by means of theatrical metaphors. For instance, 'consummate actor' is the expression used by Momigny to describe Baillot as his favourite quartet player. ${ }^{18}$ In what follows, then, I propose an archaeology of this theatrical conception of instrumental performance in early nineteenthcentury Paris. I bring the performances of Baillot's ensemble in contact with the debates and hands-on-scores experiences of an increasing separation between composers' and performers' tasks, its impact on musical notation and how performers were supposed to handle it to render the spirit of different composers or pieces. Crucially, all these aspects to do with the modern idea of the performer as a specialised interpreter of different styles of music, and by a variety of composers, were discussed resorting to theatrical imaginary.

I intend this framework as a useful alternative to theorising the role of performers in this context just on the basis of what repertoire they played. Nancy November has long brought attention to the pervasiveness of theatrical analogies in theoretical and critical writings on string quartet performance in this period. ${ }^{19}$ But scholarship on Baillot has often downplayed the theatrical dimension of music-making in his soirées and the explicit theatrical language of his treatises, possibly because deemed too audience-engaging for the Parisian who made the instrumental chamber works of Haydn, Mozart and Beethoven become 'classics' ${ }^{20}$ Put

\footnotetext{
${ }^{18}$ Jérôme-Joseph Momigny, 'Soirées ou Séances Musicales', in Encyclopédie méthodique. Musique (Paris, 1818), 2: 374.

${ }^{19}$ Nancy November, 'Theater Piece and Cabinetstück: Nineteenth-Century Visual Ideologies of the String Quartet', Music and Art, 29/1-2 (2004), 135-150. November discusses Baillot's writings arguing for a 'conversational' attitude between performers and listeners, focusing for instance on the visual stimuli that must have enhanced the listener's experience of a string quartet performance; see also her Beethoven's Theatrical Quartets: Opp. 59, 74 and 95 (Cambridge, 2013) and Cultivating String Quartets in Beethoven's Vienna (Boydell, 2017).

${ }^{20}$ Gesturing towards their role in the canonisation of Haydn, Mozart and Beethoven, Joël-Marie Fauquet's chapter on Baillot's concerts is tellingly titled 'L'idéal classique'; Fauquet, Les sociétés de musique de chambre à Paris de la Restauration à 1870, 20-112.
} 
another way, the impulse to inscribe Baillot's achievements in the history of absolute music has meant the erasure of a key aspect of his performance ideology. I suggest that Baillot's quartet soirées are best understood in a cultural entanglement of theatrical metaphors and instrumental performance: an approach that Baillot developed as a prototype in performing 'musique de quatuor', but that he held and proposed to the nineteenth-century world as a blueprint for the ideal modern performer across all genres of instrumental music.

\section{Actors and automata}

Pierre Baillot became a member of the Paris Conservatoire's violin faculty almost at its inception, in 1795. Brought in initially as a temporary replacement for his friend and more established violinist Pierre Rode (on extended leave for touring), Baillot was soon given his own class, remaining in his post at the Conservatoire for almost half a century. Diane Tisdall has recently cast new light on how Baillot's atypical career trajectory, his literary interests and early training as a lawyer in government administration, made him more invested into the Conservatoire's pedagogical project than his colleagues, the celebrated violin virtuosos Rode and Rodolphe Kreutzer. ${ }^{21}$ Among the three of them, Baillot played the most prominent role in devising musicians' training at the Conservatoire and further afield. His systematisation of teaching in the early methods for violin, cello and double bass commissioned by the Paris Conservatoire adhered to the institution's vision of creating a written and up-to-date pedagogy to replace the oral teaching practices of the ancien régime. ${ }^{22}$ According to Tisdall, a distinctive feature of these new manuals was that they sought to embody a collective, authoritative voice on each instrument. Already Baillot's first method, the Méthode de violon of 1803, was not conceived to reflect his personal performing style; it was not, to borrow from Tisdall, 'a how-to-play-like-Baillot manual'. Rather, his aim was to compile a 'body of

\footnotetext{
${ }^{21}$ Diane Tisdall, 'Pierre Baillot and Violin Pedagogy in Paris, 1795-1815' (PhD diss., King's College London, 2015), 71-91.

${ }^{22}$ See also Jean-Louis Jam, 'Pédagogie musicale et idéologie: un plan d'éducation musicale', in Jean Rémy Julien, Jean Mongrédien (ed.), Le Tambour et la Harpe, ouvres pratiques et manifestations musicales sous la Révolution (Paris, 1991), 37-48; Cynthia Gessele, 'The Conservatoire de Musique and National Music Education in France, 1795-1801', in Malcolm Boyd (ed.), Music and the French Revolution (Cambridge, 1992), 191-210; Michael Fend, Michel Noiray (ed.), Musical education in Europe (1770-1914): compositional, institutional, and political challenges, vol. 1 (Berlin, 2005).
} 
principles' concerning the art of violin playing, drawing from a selection of previous and contemporary works (by Michel Corrette, Francesco Geminiani, Leopold Mozart among others) that was to be updated as the years went by. ${ }^{23}$ The Conservatoire's agenda, in other words, was to substitute for isolated teaching voices a newly unified and institutionally approved standard: not just for the training of Conservatoire students, but for the future of the art, as it were, speaking to humanity at large.

Aside from his discussion of earlier treatises and current performing styles (such as those of Rode, Kreutzer and Paganini), Baillot's commitment to progress is also evident in revisions and republishings of his pedagogical compendium. Thirty years on, the Méthode de violon was substantially reworked into what the title-page calls a 'new method': L'Art $d u$ violon (1835). As much as updating the system with the latest technical tools, the preparation of this new treatise underscores an understanding of musical art as continuously, and necessarily, in flux. Baillot's prose deals at length with preparing performers to face the challenges brought about by the artistic and societal transformations in these decades. Even the technical sections, the reader is told, lay out their principles more precisely as a result of years of trial and error, striving to achieve a more 'scientific' grasp of the challenges. In line with the reflexivity of Baillot's approach, a new introductory section depicts the ideal musicians as consumed by the need to look out for ways to perfect their art. Quoting the English poet Edward Young, Baillot suggests that this search should occupy the musician's life entirely, and yet he shall 'die still hungry of science'. ${ }^{24}$ This exaltation of scientific productivity resonates with the utopian ideals of Saint-Simonianism, much in vogue in $1820 \mathrm{~s}$ Paris, which championed a society driven by progress and led by productive individuals, rather than landowners and their past system of privileges. ${ }^{25}$ Scientists and artists were supposed to lay down with their breakthroughs a path for others to follow. The task of musicians, according this view, was no less than the development of society.

\footnotetext{
${ }^{23}$ Pierre Baillot, L'Art du violon. Nouvelle méthode dédiée à ses élèves (Paris, 1835), 6. Tisdall argues that the search for an institutional voice is reflected in that Baillot's first treatise was published listing also Kreutzer and Rode as authors, although Rode did not contribute to the project and Kreutzer provided only one set of five exercises; see Pierre Baillot, Pierre Rode, Rodolphe Kreutzer, Méthode de violon [...] rédigée par Baillot et adoptée par le Conservatoire pour servir à l'Etude dans cet Etablissement (Paris, 1803); and Tisdall, 'Pierre Baillot and Violin Pedagogy in Paris, 1795-1815', 166-201, here 184.

${ }^{24}$ Edward Young, Les nuits d'Young, I, trans. Pierre Le Tourneur (Paris, 1827), 173; orig. published as The Complaint, or Night-Thoughts on Life, Death and Immortality (London, 1742-1745); see Baillot, L'Art du violon, 2-3, 6.

${ }^{25}$ Baillot might have come in contact with Saint-Simonian ideals through his friend Adolphe Guéroult and Eugène Sauzay, Baillot's son in law and the second violinist in his ensemble; see Fauquet, Les sociétés de musique de chambre à Paris de la Restauration à 1870, 68; and Ralph P. Locke, Music, Musicians and the Saint-Simonians (Chicago, 1986), 26, 110, 224.
} 
As a constant flow of experimentation and innovations was envisaged as the ideal status quo for the art of music, Baillot's methods can be read to answer a higher calling than simply how to play the violin: to assist performers in understanding and coping with a musical world in flux. ${ }^{26}$ Understood as institutional guides to musical progress, his two methods offer a unique perspective on the period. Both the continuities they highlight and the revisions implemented after three decades tell a story: of the transformations sweeping the musical arena in the early nineteenth century, and how performers were supposed to embrace or, at times, fight them. Perhaps the most significant musical revolution discussed in the added passages of the Art du violon is what Baillot identifies as a recent 'dramatic' tendency across genres:

It was particularly toward the end of the eighteenth century that almost all musical creations assumed a dramatic allure; music for the church was the first to use the language of passions [...]. Then came the turn of the opera, such as the music Gluck conceived to paint these same passions with energy to interest the heart [...]. The symphony, created by Haydn, made us listen to each instrument's character as well as their contributing to a general action, or the expression of a specific object. [...] The same procedure was used in Beethoven's early works and in his admirable symphonies, in which he found a way to express all passions and depict all scenes, speaking at once so successfully to the heart and to the imagination.

The progress of dramatic music has caused the replacement in instrumental music of melodies for the most part full of charm, but whose expression is vague, with more definite melody, suited to the operatic stage and to the accents of passion [...] music that seems to have been written with words in mind. ${ }^{27}$

Baillot's words exemplify a widespread understanding at the time of how music had progressed: from an aesthetic privileging imitation (via descriptive titles, characteristic pieces, dances, word painting, etc., in the works by Lully and Rameau) to one favouring the depiction of interior emotional states, with Gluck considered a major innovator in this shift. However, pace James Johnson, rather than evolving towards a more indeterminate musical

\footnotetext{
${ }^{26}$ See also Jürgen Osterhammel, The Transformation of the World: A Global History of the Nineteenth Century, trans. Patrick Camiller (Princeton, 2014), 45-76.

27 ' $\mathrm{Ce}$ fut surtout vers la fin du siècle dernier, que presque toutes les conceptions musicales prirent une allure dramatique; la musique d'Eglise fut la première à servir du langage des passions [...]; vint ensuite celle du grand Opéra, telle que Gluck l'a conçue pour peindre ces mêmes passions avec énergie pour intéresser le cœur [...] La symphonie, créé par Haydn fit entendre chaque instrument dans son caractère et concourant à une action générale ou à l'expression d'un objet déterminé. [...] Le même système fut suivi dans les premières compositions de Beethoven et dans ses admirables symphonies où il trouva le moyen d'exprimer toutes les passions et de peindre tous les tableaux, de parler à la fois avec tant de succès au cœur et à l'imagination!'. '[Le] progrès de la musique dramatique [...] a fait substituer, dans la musique instrumentale, à des chants pour la plupart pleins de charme, mais d'une expression vague, une mélodie plus positive, adaptée à la scène lyrique et aux accens [sic] de passion. [...chants] qui semblent avoir été faits sur des paroles'; Baillot, L'Art du violon, 161; emphases mine. Unless otherwise stated, translations are my own. I have chosen not to use Louise Goldberg's English translation of L'Art du violon, appeared as The art of violin (Evanston, 1991), in order to highlight important continuities between the 1803 and 1835 versions of the treatise. I see this as an opportunity to look at Baillot's original French with new eyes, spotting hitherto unexplored resonances with the other late eighteenth- and early nineteenth-century sources considered in this study.
} 
idiom (further emancipated from verbal text), according to Baillot the adoption of the language of passion in an instrumental context brought about more precise means of expression. ${ }^{28}$ An ingenious use of instrumental colours is described here as quasi anthropomorphizing, allowing one to hear a symphony by Haydn or Beethoven as a scene in which characters interact. Baillot's theatrical language in this excerpt recalls Ludwig Tieck's 1799 comparison of symphonies to dramas, as an art that captures the (inner) eye and ear at the same time. ${ }^{29}$ Deirdre Loughridge has recently revised the alleged opposition in this period between 'pure' instrumental music and its power to stimulate images in the mind of the listener. Her claim about an 'audiovisual perception' of instrumental music resonates strongly with what Baillot calls a 'dramatic allure', successfully triggering the listeners' imagination and their mind's image-forming capacities. ${ }^{30}$

The concept of a 'dramatic revolution' bringing instrumental music closer to stage or vocal genres is similarly advocated in a thread of late eighteenth- and early nineteenthcentury French theoretical writings. These texts provide further insights into the ideal attitude envisaged for the performer within this shift. In 1785, the naturalist and music theorist Bernard Germain de Lacépède comments:

In a concert, who must [the musician] entertain and interest for a long time? A great number of spectators, who have nothing in front of them except the performers [...] and to whom we can only narrate what would otherwise have been shown to them in the theatre. The musician therefore will have to put more strength and vitality in [depicting] his images, [as if by] adding some further paint than he would have done, and in this way to compensate for the interlocutors and for the scene that one won't have before the eyes. ${ }^{31}$

Rather than being shown different interlocutors or their interactions in a plot, the audience at a concert can only be told such a story. Hence the need for the performers to compensate by making their 'narration' vivid enough to appear animated. Such an overlap between oratory, theatre and music-making in the language of effective delivery can be found also in Diderot's

\footnotetext{
${ }^{28}$ For a convincing critique of Johnson's narrative as relying primarily on a thread of eighteenth-century aesthetics that characterised vocal and instrumental music in opposition, see Mary Ann Smart, 'Review of Listening in Paris: A Cultural History by James H. Johnson', 19th-Century Music, 20/3 (1997), 293.

${ }^{29}$ Wilhelm Heinrich Wackenroder and Ludwig Tieck, Phantasien über die Kunst (Hamburg, 1799), 96.

${ }^{30}$ Deirdre Loughridge, Haydn's Sunrise, Beethoven's Shadow: Audiovisual Culture and the Emergence of Musical Romanticism (Chicago, 2016), 13-15. See also Richard Will, The Characteristic Symphony in the Age of Haydn and Beethoven (Cambridge, 2002) 14-17.

31 'Dans les concerts [...] qui doit-il amuser \& intéresser pendant longtemps? Un grand nombre de spectateurs qui n'ont devant les yeux que des musiciens, [...] auxquels [...] on ne peut que raconter ce qu'on leur auroit montre sur un théâtre [...] Le musicien devra donc tâcher de mettre encore plus de vivacité \& de force dans ses images, d'ajouter en quelque sorte de nouvelle peinture à celles qu'il auroit faites, \& de suppléer ainsi aux interlocuteurs \& ainsi au lieu de la scène que l'on n'aura pas sous les yeux.' Bernard Germain [Étienne Médard de la Ville-sur-Illon, Comte de] Lacépède, Poétique de la Musique (Paris, 1785), 2: 321-22; emphasis mine.
} 
Encyclopédie (1751-1772). Statements such as 'the pronunciation is the orator's action' or 'the speaker who composes his declamation is a comedian who practices' employ theatrical metaphors to exemplify how, although via different means, a convincing performance in the court or on a stage is meant to achieve the same enthralling effect on the audience. ${ }^{32}$ The task of the musician or the orator is to find a balance of effects in their own medium (adequate to the given genre or occasion) to stimulate the mind of the listeners and leave them theatrically spellbound: as if they were witnessing a much more immersive, multi-sensory spectacle. Discussing specifically the performance of chamber works, Lacépède advises the musicians to "never forget that this music has the utmost dramatic shape. One should be able to recognise a course of passions and that of an interesting action; to notice a beginning, a middle, an end; some sort of plot and a denouement. Those who perform this music should be able to follow in it a drama of which they will be the actors'. ${ }^{33}$ Identified as the actors in this stage-less drama, performers are entrusted with bold interpretative gestures as if they were impersonating characters and acting out for the audience twists and turns of an imagined plot. Put another way, instrumental music requires performers to offset its limited referentiality. This is best achieved by musical nuances so expressive to the point of mimicking actions that cannot be seen or dialogues that cannot be heard.

The notion that modern instrumental music such as that of Haydn, Mozart and Beethoven called for a key intermediary to make it sound as the unravelling of an imaginary drama can be observed at play in Jérôme-Joseph de Momigny's famous verbalisation of Mozart's Quartet K 421. In his 1806 composition treatise, Momigny included a detailed analysis of the first movement of the quartet, followed by an appendix where the score is underlaid with a text to help convey to the reader the piece's expressive qualities. ${ }^{34}$ The textual inserts add up

\footnotetext{
${ }^{32}$ Edme-François Mallet, 'Déclamation', in Denis Diderot, Jean le Rond d'Alembert (ed.), Encyclopédie, ou dictionnaire raisonné des sciences, des arts et des métiers, vol. 4 (Paris, 1754), 680-92. Since the foundation of Paris Conservatoire in 1795, the teaching of music and acting were reunited under the same roof, with a dedicated 'department of declamation' employing mostly personnel from the Comédie-Française.

33 'Musiciens, n'oubliez jamais [...] que ces ouvrages présentent le plus possible la forme dramatique [...]; que l'on y reconnoisse la marche des passions, \& en quelque sorte celle d'une action intéressante; que l'on y remarque un commencement, un milieu, un fin [...] une espèce d'intrigue, un dénouement; [...] que-ceux qui l'exécuteront y puissent suivre toutes les parties d'un drame dont ils seront les acteurs.' Lacépède, Poétique de la Musique, 2: 343-44.

${ }^{34}$ Jérôme-Joseph Momigny, Course complet d'harmonie et composition (Paris, 1803-06), 1: 371; 3: 109-56. See Edward Klorman, Mozart's Music of Friends: Social Interplay in the Chamber Works (Cambridge, 2016), 5270; and William O'Hara, 'Momigny's Mozart: Language, Metaphor, and Form in an Early Analysis of the String Quartet in D Minor, K. 421', Newsletter of the Mozart Society of North America, 21/1 (2017), 5-10. The practice of attaching words to works composed for a purely instrumental ensemble was not unusual. In the same treatise, Momigny provides similar textual additions to Haydn's Symphony No. 103 'Drumroll' and a fugue for keyboard by Handel. Pedagogical contexts aside, song versions were published for instance of Haydn's quartets
} 
to a dramatic scene, in which the character Dido laments her suffering as she is being abandoned by her lover Aeneas. In this respect, Momigny's intervention on the written page for his readers is akin to what Lacépède ideally expected from the performers of this music for an audience: 'to add further paint', a story that dramatizes the score. What is most significant, for a comparison with actual performances of the piece, is that Momigny discusses his chosen dramatic narrative as only one of many plots suitable for this movement. Another tragic story featuring a character caught between conflicting emotions (such as desire and rejection in Dido's case) would do just as well to characterise twists and turns of the piece. ${ }^{35}$ In this conception, the mid-figure entrusted to disclose music's expressive potential has a clear creative task and agency inventing the means to make instrumental music sound as it should.

As with any revolution, however, the dramatization of instrumental music had its side effects. Some of these, exacerbated by the opening up of music practices to a larger segment of society in these decades, were feared to undermine the role of performers as skilled and eloquent actors. Baillot expressed his concerns in two letters from 1796 to his friend and private student François de Montbeillard:

The rage for music extends every day with a violence that makes me fear that this is an incurable disease. [...] The musicoragicomanie [sic] wreaks havoc inside our walls - it is impossible to escape: [...] there isn't a circle that hasn't become a concert, all the tables are now pianos, all the women musicians, all the men little Garats [i.e. a famous singer]. Music has taken the place of gossip. One makes noise at the expense of delicate ears, as once one made humour at the expense of his neighbour; within a quarter-hour one has sung three of Gluck's operas, travelled through some Italian Finali, played pont neufs, potpourris, Romances and a Grand Sonata by Steibelt. Performance goes faster than thought; when the voices are a little tired, we attack the quartet [...] and the four [individuals] concerting are cherished, celebrated, caressed, and admired like the puppets that once one bought at the fair. ${ }^{36}$

Op. 33 and Pleyel's quartets Op. 1 and 2; see Anthony van Hoboken, J. Haydn, Thematisch-bibliographisches Werkverzeichnis (Mainz, 1957-78), 395-401; Rita Benton, Ignace Pleyel: A thematic catalogue of his compositions (New York, 1977), 99-111.

${ }^{35}$ Momigny, Course complet d'harmonie et composition, 1: 371 . The understanding of music as waiting to be appropriated with different 'plots' can be seen at play also in other spheres of Parisian music-making in this period. Revolutionary songs and hymns were often given new texts reflecting current events and ideological shifts; see Ralph P. Locke, 'Paris: Centre of Intellectual Ferment', in Alexander L. Ringer (ed.), The Early Romantic Era: Between Revolutions, 1789-1848 (London, 1990), 35.

36 'La rage de la musique s'étend chaque jour avec une Violence qui me fait craindre que ce ne soit une maladie incurable'; 'La maladie va toujours son train. La musicoragicomanie [sic] fait des ravages dans nos murs - il est impossible de s'y soustraire: [...] Il n'est pas un cercle qui ne soit devenu un concert: toutes les tables sont des pianos, les femmes, des musiciennes, les hommes, de petits Garat, la musique a remplacé la médisance; on fait du bruit au dépens des oreilles délicates, comme autrefois on faisait de l'esprit a dépens de son prochain: dans l'espace d'un quart d'heure on a chanté 3 opéra de Gluck, on a parcouru quelques finales italiens, on a joué des ponts neufs, des pots-pourris, des Romances et une Grande Sonate de Steibelt; l'exécution va plus vite que la pensée; quand le Voix sont un peu fatiguées, on attaque le quatuor, [...] les Quatre Concertans sont choyés, fêtés, caressés, admirés, comme les Pantins qu'on achetait jadis à la foire'; Pierre Baillot to François de Montbeillard, 9 September and 6 October 1796, http://bruzanemediabase.com/Fonds-d-archives/Fonds-Baillot. 
The dystopian scenario depicted by Baillot is that of various kinds of music playing at the same time from behind almost every Parisian doorstep, merging as if in an indistinct urban noise. Its proximity and ubiquity made it inescapable. The image of music-making as having replaced gossip conveys a sense of superficiality attached to its practice, as it were, that of a capricious pastime. The danger of a performance that goes 'faster than thought' was to handle music carelessly, paying no attention to the nuances required to perform different repertoires, or even different sections and characters within each piece. Playing in fifteen minutes a bit of everything - new and old, low and high music - likely resulted in everything being played in the same manner. Music's enhanced dissemination and accelerated pace of consumption came at a cost. Rather than depicting vividly a story of characters and their feelings, in this scenario performance is somehow de-humanised. Musicians are mere puppets capable of just one facial expression: a mere shadow of the skilled actors they ought to be. ${ }^{37}$ They are cherished, but like soulless figures controlled via invisible strings.

Baillot had further reasons to lament the fact that performers were treated like puppets. As a rich palette of nuances was key to modern instrumental performance but difficult to create on the spot, composers saw fit to help by notating into their scores nuances that could come in handy in a performance 'going faster than thought': that is, for performers who did not have the time to think and invent. Scholars have often considered the proliferation of performing indications in music from the late eighteenth and early nineteenth century the result of an expanding amateur-driven market for sheet music and, more generally, proof of a new authority of composers and their scores over performers and their performances. ${ }^{38}$ Baillot's statements help reframe this revolution on the page as a practical response to the modern speed and spread of consumption, affecting both amateur and professional musicians

\footnotetext{
${ }^{37}$ Displays of automata such as Jacques de Vaucanson's 1738 mechanical flute player fed into contemporary debates about the roles of inspiration and the replacement of human functions by manufactured mechanical equivalents. Whether welcomed with anxiety, curiosity or fascination, musical automata remained a talking point in natural philosophy, popular science texts and music theory for most of the eighteenth and early nineteenth century; Jacques de Vaucanson, Le mécanisme du fluteur automate (Paris, 1738). See also Annette Richards, 'Automatic genius: Mozart and the mechanical sublime', Music and Letters, 80 (1999), 366-89; John Tresch, The Romantic Machine: Utopian Science and Technology after Napoleon (Chicago, 2012); and Adelheid Voskuhl, Androids in the Enlightenment: Mechanics, Artisans, and Cultures of the Self (Chicago, 2013).

${ }^{38}$ See for instance Goehr, The Imaginary Museum of Musical Works, 216-42. For a compelling account of how consumers' increased access to music during the eighteenth century fostered anxieties in assuming a shared level of know-how to handle musical notation, see Roger Mathew Grant, 'Eighteenth-Century Mediations of Music Theory: Meter, Tempo, and Affect in Print', in Emily H. Green, Catherine Mayes (ed.), Consuming Music: Individuals, Institutions, Communities, 1730-1830 (Rochester, 2017), 102-124.
} 
but in crucially different ways. A score bearing more performing instructions could, indeed, partially compensate for inexperienced players who were not able to distinguish 'twists and turns' in the 'plot' and create suitable means of expression. ${ }^{39}$ But it could also make accomplished performers lazy. In his 1835 treatise, Baillot explicitly warns how modern scores' over-specification could cause the extinction of the performers' creative attitude (the 'genius of performance', as Baillot calls it), which he believed at the very heart of what it meant to perform music effectively. ${ }^{40}$ As opposed to those clean pages of the past, musicians would now find written out 'not only ornamentation, but also nuances, fingerings, bow strokes, and the character of the piece, as well as all the main elements of the [manner of playing it]' ${ }^{41}$ Skilled performers-actors might in these circumstances lose the habit of exercising their sensitivity in inventing dynamics, qualities of sound, ornamentation, nuances of tempo, etc.

The profusion of performing indications in instrumental works such as those by Haydn, Mozart and Beethoven was perceived by Baillot as a true sign of progress. Such scores attempted to accommodate instrumental music's new 'dramatic' disposition and modern performance conditions. Yet they also altered how musicians were prompted to use the musical text. That the newly detailed notation challenged what defined the roles of performers and composers in the act of music-making is particularly evident when considering the contemporary Parisian discourse about the concepts of 'character' (caractère) and 'accent' (accent). Following Castil-Blaze, Baillot defines 'character' as the general colour chosen by the composer to capture the listener's soul. While character is plotted by the composers, 'accent' concerns the performers only, encompassing all the means they use to translate the character; means that for the most part cannot be specified or are only very vaguely indicated. ${ }^{42}$ As with the expressive nuances of theatrical actors, attempting to notate

\footnotetext{
${ }^{39}$ Baillot, L'Art du violon, 161; 156-7.

${ }^{40}$ Baillot, L'Art du violon, 162.

41 '[Les compositeurs] ont non seulement noté les Ornemens [sic], mais encore indiqué les Nuances, les Doigters, les Coups d'archet, le Caractère, et tous les principaux éléments de l'accent.', Baillot, L'Art du violon, 157. I discuss the concept of 'accent' below. For a discussion of Haydn's string quartet as groundbreaking exercises in detailed notation, see Mary Hunter, 'Haydn's string quartet fingerings: communications to performer and audience', in Engaging Haydn: Context, Culture, and Criticism, 281-301; and James Webster, 'The Significance of Haydn's Quartet Autographs for Performance Practice', in Christoph Wolff (ed.), The String Quartet of Haydn Mozart, and Beethoven: Studies of the Autograph Manuscripts (Cambridge, MA, 1980), 62-96.

42 Both Momigny and Baillot use the verb 'to translate' (traduire) in discussing instrumental music's need of a middle figure who can 'reveal a million things that cannot be understood without him', Momigny, Course complet d'harmonie et composition, 1: 380 . Yet what is being 'translated' is not the composer's notation, but rather the composer's feelings as imagined by the performer in deciphering a succession of characters: 'translate everything, bring everything to life, let pass into the soul of the listener the feeling that the composer had in his',
} 
musical accent would be in vain, even with the aid of all possible signs. ${ }^{43}$ In his Dictionnaire de musique moderne published in 1821, Castil-Blaze explains:

The [musical accent] is a more pronounced energy attached to a particular note in the measure, [a feature] of the rhythm, of the musical phrase, [which one produces] 1) by articulating this note more strongly or with graduated strength; 2) by prolonging its time value; 3 ) or in detaching it from the other [elements] with a distinctive intonation, flatter or sharper.

[The determined pitch of a voice or an instrument] is not where one should look for the accent, but in the manner of creating such intonation. Therefore, each singer, each instrumentalist will bestow a distinctive accent to the same melody. The accent belongs entirely to the performance; thus, like the latter, it varies depending on whether the performer has more or less talent and sensitivity. ${ }^{44}$

Accent can only imperfectly be included into notation because it is what performers do with notation. Castil-Blaze stresses how each performer is expected to render differently the character of a phrase and even the pitch of a single note. As with Momigny's verbalisation, a particular 'narrative of accents' (made from choices of tempo, trattenuti, nuances of intonation, dynamics, articulation, etc.) will always be one among infinite possible renditions of a given piece. The expectation in both Castil-Blaze's and Baillot's conception is that performers should take ownership of their nuances, acting as narrators that imagine 'the feeling the composer had in his soul' and re-create it their own way. Only if they were not up to this task should they follow step by step the - inevitably deficient - instructions in the score. $^{45}$

Baillot's preoccupation about composers attempting via the score to do some of the performers' work (thus making it suited to a broader range of uses and users) has an affinity with the risks discussed in contemporary debates on the division of labour. Enlightenment writers such as Henri-Louis Duhamel du Monceau, Adam Smith and Charles Babbage

Baillot, Méthode de violon, 163; L'Art du violon, 266. See also Hunter, 'To Play as if from the Soul of the Composer', 367-8.

${ }^{43}$ Baillot, L'Art $d u$ violon, 192-93. For an almost identical formulation about the impossibility to notate the nuances of expression of actors in the theatre, see Mallet, 'Déclamation', in Diderot, d'Alembert (ed.), Encyclopédie, vol. 4, 690, encapsulated in the adage: 'La parole s'écrit, le chant se note; mais la déclamation expressive de l'âme ne se prescrit point'. See also Jean Mauduit-Larive, Cours de déclamation prononcé à l'Athénée de Paris, vol. 2 part 1 (Paris, 1804-10), 13.

44 'C'est une énergie plus marquée attaché à un trait, à une note particulière de la mesure, du rythme, de la phrase musicale, soit $1^{\mathrm{er}}$ en articulant cette note plus fortement ou avec une force graduée; $2^{\mathrm{e}}$ en lui donnant une valeur du temps plus grande; $3^{\mathrm{e}}$ en la détachant des autres par une intonation distincte au grave ou à l'aigu. Dans la musique l'intonation de la voix ou de l'instrument étant déterminée, ce n'est pas là qu'il faut chercher l'accent mais dans la manière de faire cette intonation; ainsi chaque chanteur, chaque instrumentiste donnera un accent particulier à la même mélodie. L'accent appartient en entier à l'exécution; il éprouvera donc comme elle des variations selon que l'exécutant aura plus ou moins de talent ou de sensibilité', [François Henri Joseph Blaze] Castil-Blaze, 'Accent', in Dictionnaire de musique moderne (Paris, 1821), 8, quoted in Baillot, L'Art du violon, 193.

${ }^{45}$ Baillot, L'Art du violon, 162-63. 
discuss how the growth in production naturally drives a trade to divide itself into specific branches, which become ever more independent once its workers start to specialise rather than operating on the whole production chain. Increased productivity is ensured by the worker's enhanced dexterity in performing his single task, as well as saving time needed to switch from one job (and the skill) to another. ${ }^{46}$ However, Smith anticipates this increased division of labour to have different impacts depending on the worker's specialisation. For those using 'the head more than the hands', like composers, invention and intellectual virtues are safely kept alive. But those dealing primarily with mechanical or physical tasks acquire manual dexterity while their intellect will grow torpid from lack of exercise. They are more likely to become oblivious, insensitive, almost 'non-human' automata, like the musicianspuppets mentioned in Baillot's dystopian description of a modern concert. ${ }^{47}$ Following Smith's scenario, performers risked stifling their imagination if someone else had notated enough instructions for them simply to execute them. They risked moving from being consummate actors to mere physical workers, virtuosos of some mechanisms of their body: hands and voices at the service of somebody else.

Aside from warning performers not to relinquish invention of accent, Baillot devised a long-term strategy to counter the approach that modern scores might foster. To avoid slipping into the habit of merely following someone else's instructions, modern performers should study (and play regularly) early music: music written before the dramatic revolution. In this older repertoire, they will always be confronted by the lack of - or at least less detailed instructions concerning the manner of playing. Where composers have not attempted to notate very much, performers will naturally start using their imagination to invent an imagined plot and a narrative of accents. By practising their inventiveness in this music and never losing sight of it, performers will be less likely to give up their creative attitude when

\footnotetext{
${ }^{46}$ Using a model first discussed by du Monceau, Smith provides an example of division of labour in a pin factory; Adam Smith, An Inquiry into the Nature and Causes of the Wealth of Nations (London, 1776), 1: chapter 1, paragraphs 5-10. Smith's writing were widely known and discussed on the continent. The first French translation of the Wealth of Nations appeared in 1778: Smith, Recherches sur la nature et les causes de la richesse des nations (La Haye); between 1778 and 1802, no less than seven different French translations became available; see Gilbert Faccarello, Philippe Steiner, 'The Diffusion of the Works of Adam Smith in the French Language: An Outline History', in Keith Tribe (ed.), A Critical Biography of Adam Smith (London, 2002), 6365; Kenneth E. Carpenter, The Dissemination of the Wealth of Nations in French and in France, 1776-1843 (New York, 2002).

${ }^{47}$ Smith, Wealth of Nations, 5: chapter 1, paragraphs 178-80. Much in line with the fear for the unhuman and Baillot's puppet-musician, in 1820s Paris commentators often dubbed the musical innovations heralded by the like of Rossini and Paganini as 'mechanical', reducing music 'to the mere use of one's physical means' and depriving it 'of those qualities given by the power of one's morality'; Henri-Montan Berton, De la musique mécanique et de la musique philosophique (Paris, 1826), 40; see also Olivier Bara, 'Les voix dissonantes de l'anti-rossinisme français sous la Restauration', Chroniques italiennes, 77/78 (2006), 107-125.
} 
handling modern scores. ${ }^{48}$ Put another way, modern instrumental music in this conception is not assigned a different ontological status. The abundance of indications does not make it worthy of preservation and delivery as it stands, as if already complete on the printed page. Through the lens of Baillot's and Castil-Blaze's writings, the over specification of performing indications rather prompted a sense of disorientation comparable, for instance, to that experienced by contemporary road users. As traffic increased in the mid-nineteenth century, road signing spread rapidly and unevenly: a puzzling mixture of warnings, weight restrictions and direction signs started invading the streets. Especially at the beginning, such signs were not of standard design, there were no regulations to restrict their use and they were so common that users often elected to ignore them. ${ }^{49}$ Baillot unmistakably urges performers not to feel constrained by what was being indicated in ever-greater detail, and to keep using their instinct and mental faculties to choose how to proceed, as they did in the past. Baillot's answer to navigate his epoch's historic changes was, ultimately, history itself. ${ }^{50}$

\section{Performing progress}

In line with what he advocated in his treatises, the chamber music soirées that Baillot organised and led since 1814 were dedicated both to music of the past and to new repertoire. Only four years after the series had been inaugurated, Momigny described it enthusiastically as 'concerts per subscription that a few distinguished artists give in their homes and are most

\footnotetext{
${ }^{48}$ Baillot, L'Art du violon, 162.

49 The advent of railways and canals as alternative modes of transport in the nineteenth century affected the existing roads system as they overlapped, resulting in a range of situations local authorities were suddenly urged to regulate; see Clay McShane, 'The origin and globalisation of traffic control signals', Journal of Urban History, 25 (1999), 379-383.

${ }^{50}$ The interest in rescuing the past witnessed a new ferment in the early nineteenth century: what was being lost in precipitous innovations could be recorded and collected, both privately and in museum or libraries, so that people had something to hold on to, even be nostalgic about. See Tom Stammers, 'The bric-a-brac of the old regime: collecting and cultural history in post-revolutionary France', French History, 22/3 (2008), 304-305. Diane Tisdall shows how Baillot's pedagogical interest in the music of the past extended to the repertoire that violin students would have been learning at the Conservatoire, using editions of older violin music issued by the Conservatoire's publishing house and Jean-Baptiste Cartier's selection of violin works by Corelli, Handel, Tartini, Geminiani, Locatelli, Ferrari, Stamitz, Gaviniés, Nardini and Viotti; see Jean-Baptiste Cartier, L'Art du Violon, ou Collection choisie dans les sonates des écoles italienne, françoise et allemande (Paris, 1799); Tisdall, 'Pierre Baillot and Violin Pedagogy in Paris, 1795-1815', 190-93; and Katharine Ellis, Interpreting the Musical Past: Early Music in Nineteenth Century France (Oxford, 2005), 3-15.
} 
suited to spread the taste for good music; [...] those of Mr Baillot are unquestionably of the

first rank [...] His purpose in establishing them, was to devise a course of ancient and modern music, from Corelli to the present day'. ${ }^{51}$ In the 1830s, François-Joseph Fétis and Joseph d'Ortigue similarly identified the value of the soirées in that they showcased the progress of music:

[Baillot's thought was to] make heard, in a gradual progression of styles, the various transformations brought about in the genre [of string quartet and quintet] by the spirit, so different, of Boccherini, Haydn, Mozart and Beethoven. ${ }^{52}$

The programme as a whole is a history lecture. In a two-hour performance, the art and its traditions will unfold before our eyes. Boccherini, with his antique and naive manners, breathes some scents of the Middle Ages. Haydn represents a perfected society full of elegance. More tumultuous, more passionate in Mozart, it seems immensely eager to develop. Beethoven, in his reveries and up to his sublime follies is the image of a civilisation that overflows, overwhelms. Well then! Mr Baillot is the man of all these epochs. He not only transports himself to the time indicated by the author's name, but he also identifies himself with the personality of the composer. ${ }^{53}$

The notion of music history as a progressive growth corresponding to the stages of human civilisation was a common historiographical trope in this period. ${ }^{54}$ But that critics went so far as to endow Baillot with time-travelling abilities bears testimony to the novelty of the ensemble's approach. William Weber argues that concert programmes gained increasing historical diversity only later in the nineteenth century, as they abandoned the mixture of

51 'Concerts par souscription, que quelques artistes distingués donnent chez eux, \& qui sont très-propres à propager le gout de la bonne musique; [...] les séances de M. Baillot tiennent, sans contredit, le premier rang [...] Son dessein, en les établissant, était de former un cours de musique ancienne \& moderne, depuis Corelli jusqu'à nos jours', Momigny, 'Soirées ou Séances Musicales', in Encyclopédie méthodique. Musique, 2: 374.

52 'Pour y faire entendre, dans une progression de styles, les diverses transformations imprimées à ce genre de musique par le génie si différent de Boccherini, de Haydn, de Mozart et de Beethoven', François-Joseph Fétis, 'Baillot', in Biographie universelle des musiciens et bibliographie générale de la musique (Bruxelles, 1837), 1: 41.

53 'Le [...] programme est un cours d'histoire tout entier. Pendant une séance de deux heures, l'art et ses traditions vont se dérouler à nos yeux. Boccherini, avec ses allures antiques et naïves, respire je ne sais quel parfum de moyen âge. Haydn représente une société perfectionnée et pleine de raffinemens [sic]. Plus tumultueuse, plus passionnée dans Mozart, elle semble pressée d'un immense besoin de développemens [sic]. Beethoven, dans ses rêveries et jusque dans ses folies sublimes, est l'image d'une civilisation qui surabonde, qui déborde. Eh bien! M. Baillot est l'homme de toutes ces époques. Non seulement il se transporte au temps qu'indique le nom de l'auteur, mais encore il s'identifie avec le compositeur lui-même', Joseph d'Ortigue, Le balcon de l'Opéra (Paris, 1833), 266-69. The text first appeared as a review of the séance of 22 February 1831, L'Avenir (28 February 1831), 1.

${ }^{54}$ Sociocultural evolutionism, an Enlightenment fascination with explaining the evolution of humankind both biologically and socially, supported the notion of fixed 'stages' through which human societies progress. As early as 1795, the Marquis de Condorcet listed ten such stages, from a primitive state of nature towards something resembling contemporary industrial Europe; see Nicolas de Caritat Marquis de Condorcet, Esquisse d'un tableau historique des progrès de l'esprit humain (Paris, 1795); see also Joseph d'Ortigue, De la Guerre des dilettanti, ou de la révolution opérée par M. Rossini dans l'opéra française; et des rapports qui existent entre la musique, la littérature et les arts (Paris, 1829), 61-65, 70. 
genres and forces (chamber, orchestral, vocal, instrumental, etc.). ${ }^{55}$ Baillot's series can be seen as a remarkably early instance of this phenomenon. His quartet soirées recreated the variety of a mixed format in terms of different 'epochs' and styles of music performed by the same ensemble. ${ }^{56}$

For over a hundred and fifty chamber concerts between 1814 and 1840, Baillot held to the same programme structure: five or six pieces, often starting with a Boccherini quintet or quartet ( $84 \%$ of the séances). Then followed three core works such as a Haydn or Beethoven quartet, a Mozart quintet and a quartet by Cherubini or Onslow among other contemporary Parisian composers; and each soirée concluded (91\% of the séances) with a brilliant solo for the first violin - always performed by Baillot - such as a romance or one of Baillot's own air variées, for which the other members of the ensemble provided an accompaniment. ${ }^{57}$ Judging from the composers typically featured, the label of 'music of the past' was not understood in absolute terms, with a chronology of works and authors in mind. That Boccherini (who died in 1805) was made to belong to this category, while Mozart (who died in 1791) and Haydn (in 1809) were not, suggests a distinction little to do with actual dates or even a practical division between dead and living composers. ${ }^{58}$ Rather, both Fétis and d'Ortigue stress how the soirées made it possible to appreciate the differences between these composers as they were set in place by the progress of music. It was, in other words, the more pronounced dramatic qualities of recent instrumental works such as those by Haydn, Beethoven or Cherubini that had made Boccherini 'antique'. The merit of Baillot's project resided precisely in his and his ensemble's ability to highlight these differences in performance. Instead of an indistinct cluster of musical styles inundating the city, a spectacle so orderly and consistently structured aided the audience in becoming acquainted with the different stages of musical progress. Although there was no hope of a tidy musical modernity, Baillot and his ensemble were fighting what they perceived to be a large-scale degeneration of artistic practices by

\footnotetext{
${ }^{55}$ See Weber, The Great Transformations of Musical Taste, 35, 85-88.

${ }^{56}$ To draw a comparison with the Viennese equivalent of Baillot's venture, the quartet concerts led by Ignaz Schuppanzigh from 1804 did not include 'music of the past', focusing almost exclusively on contemporary Viennese composers. Schuppanzigh narrowed further his stylistic purview by largely excluding virtuosic and lighter pieces, a key facet of the 'miscellaneous' concert that Baillot retained as the closing number for almost all of his soirées; see John M. Gingerich, 'Ignaz Schuppanzigh and Beethoven's Late Quartets', The Musical Quarterly, 93 (2010), 450, 513.

${ }^{57}$ Percentages are given here on the basis of Fauquet, Les sociétés de musique de chambre, 50-53.

${ }^{58}$ The table of composers (sorted in 'morts' and 'vivans') in appendix to Baillot's second method was likely conceived as an aid to violinists in providing the correct details when advertising their own concerts (another symptom of the gradual historicisation of concert programmes, with the relevant dates being ever more often specified next to the name of each composer); see Weber, The Great Transformations of Musical Taste, 35.
} 
eloquently acting out different musical styles, epochs or even specific composers, and educating their public to distinguish them.

Baillot's ability to impersonate 'men of different epochs' probably struck commentators: in these concerts, uncommonly, the same musicians sailed through a great variety of pieces; and, pieces that for the most part they had not composed. ${ }^{59}$ Yet this versatility was neither considered peculiar nor suited only to the performance of chamber music. According to Baillot, a quartet concert was an ideal environment for performers to put their nuancing skills to use, as the audience on such occasions tended to be 'smaller but more enlightened: an audience that education has made more critical and sensitive' to the players' efforts to characterise different styles. But this repertoire - and the performers' approach to it - 'could serve as a model for all other instrumental genres' ${ }^{60}$ Indeed, a key continuity between Baillot's treatise of 1803 and that of 1835 is that both rank such impersonations carried out by the performer as the most vital quality and the highest level any professional musician should aspire to. Thirty years apart, with many other aspects of the profession conspicuously in-flux, Baillot held to the same definition of the ideal performer:

\begin{abstract}
He is the one who can seize at a glance the different characters of music, the one who by a sudden inspiration identifies himself with the genius of the composer, follows it in all its intentions and reveals them with equal ease and precision; the one who goes as far as to sense in advance which effects to use to let the composer's intentions shine more brightly, and gives to his playing the colour that suits the genre of an author. [...]
\end{abstract}

[The genius of performance is the one] who can switch at once to a different expression, adapt himself to all styles, to all manners of playing [... he can] penetrate the spirit of a piece to the point of lending it charms that are nowhere indicated, creating effects that the author usually leaves to the instinct. ${ }^{61}$

If read independently of Baillot's plea that performers invent their own nuances even when composers have attempted to notate them, this passage can be easily misunderstood. It could be thought a recommendation to render with utmost precision the performing instructions

\footnotetext{
${ }^{59}$ Diane Tisdall stresses how Baillot's ideology was shaped by his uncommon trainings, which led him to focus on the interpretation of music by others rather than following the more typical path of the virtuoso composing and performing his own music (as did Baillot's colleagues at the Conservatoire, Kreutzer and Rode); see Tisdall, 'Pierre Baillot and Violin Pedagogy in Paris, 1795-1815', 71-91.

${ }^{60}$ Baillot, L'Art du violon, 262.

61 'C'est lui qui saisit d'un coup d'œil les différens caractères de la musique, qui, par une inspiration soudaine, s'identifie avec le génie du compositeur, le suit dans toutes ses intentions et les fait connaître avec autant de facilité que de précision, qui va jusqu'à pressentir les effets pour les faire briller avec plus d'éclat, qui donne au jeu d'un instrument cette couleur qui convient au genre d'un auteur; qui sait [...] passer tout-à-coup à une expression différente, se plier à tous les styles, à tous les accens; [...] se pénétrer du génie d'un morceau jusqu'à lui prêter des charmes que rien n'indique, aller même jusqu'à créer des effets que l'auteur abandonne souvent à l'instinct'; Baillot, Méthode de violon, 163; Baillot, L'Art du violon, 266.
} 
already in the score. But given his discussion earlier in the treatise about the detrimental effects of this division of tasks between composers and performers, Baillot's advice to 'follow the genius' (that is, the spirit) of the composer 'in all its intentions' must refer to something else.

As the string quartet concert was considered ideal terrain for nuanced impersonations of different composers or styles, the library of annotated parts used by Baillot's ensemble can help clarify this key aspect of his performance ideology. Pencil entries are more consistent in Baillot's parts (those for the first violin), but it is unlikely that they were prepared as a finite set of instructions for teaching or publication purposes, as it would become frequently the case in the second half of the century. ${ }^{62}$ Considering Baillot's notational habits throughout his library, and given the violinist's own predicaments on the impossibility of notating nuances in full, in the case of these chamber concerts the annotations are best understood as working notes, jotted down for the private use of the ensemble while devising a narrative of nuances for a specific performance. ${ }^{63}$ While occupying a liminal stage of the interpretative process (and being often visibly subject to changes), these pencil marginalia capture glimpses of the general attitude with which Baillot approached his task of inventing nuances beyond what he found in print. In this respect, his annotated part of Boccherini Quintet Op. 11 n. 6 L'Uccelliera well illustrates his proactiveness (see musical example 1a). ${ }^{64}$ Judging from his added pencil clues, for instance, printed slurs are evidently treated as part of the general character that Boccherini intended to convey, not as implying bowings to be executed. Bowings and articulation are instead consistently supplied by Baillot, hence evidently thought to pertain to 'accent'. In the short excerpt below (see musical example 1b), he wrote an upbow indication, separated the printed slur into two bowings (resulting in a different phrase accentuation) and put a staccato dot on the last note.

\footnotetext{
${ }^{62}$ See Clive Brown, 'The Evolution of Annotated String Editions', in CHASE, http://mhm.hud.ac.uk/chase/article/the-evolution-of-annotated-string-editions-clive-brown/. ${ }^{63}$ For a discussion of the methodological feasibility of putting performers' annotations and marginalia under academic scrutiny see Fabio Morabito, 'The Score in the Performer's Hands: Reading Traces of the Act of Performance as a Form of Analysis?', Music Theory Online, 22/2 (2016). Baillot's annotated parts are available in Ressources numériques autour de la musique romantique française, http://bruzanemediabase.com/Fonds-darchives/Fonds-Baillot and CHASE, University of Huddersfield, http://mhm.hud.ac.uk/chase/.

${ }^{64}$ Luigi Boccherini, Sei Quintetti Per due Violini Alto et due Violoncelli Concertanti Op. XIII Libro primo di Quintetti (Paris, [?1785]), Quintetto VI, Paris, Bibliothèque nationale, Fond Lainé, Carton 5. The edition is part of a vast collection containing ninety-three Boccherini Quintets printed in instalments by different Parisian publishers (Boyer, Sieber, Le Duc, Nadermann, Imbault, Pleyel). Baillot had them bound together in one volume per part: violin I, II, viola, cello I, II (5 vols.). Each volume shows the same continuous red-ink numeration of quintets in Baillot's hand. Baillot's indications for up- and down-bow are placed upside down compared to today's norm, resembling rather the actual shape of head and frog of the bow.
} 
[INSERT MUSICAL EXAMPLE 1A AND 1B ABOUT HERE]

What is striking about Baillot's pencil annotations, and overall attitude in devising nuances, is their level of detail. For instance, in the example above, the added staccato dot seems to imply a separation of the last note from the previous one, as if a very short rest was in place. This kind of device is discussed by Baillot in relation to long-established notions of musical punctuation. Particularly in his second method of 1835 , he stresses how performers should actively devise small pauses and unwritten accentuation to group notes as if they were words or sentences for intelligible delivery:

Notes are used in music just as words are used in discourse; they serve to constitute a phrase, to make sense [...]. But light separations or pauses of very short durations are not indicated by the composer. It is necessary then that the performer introduces them, whenever he sees the need. ${ }^{65}$

Such a manifestly rhetorical model of performance is often considered to witness a decline in the early nineteenth century. ${ }^{66}$ Yet Baillot's pedagogy and the many examples of added 'musical punctuation' in his annotated parts seem to point in an opposite direction. Indeed, in this light, even his pencil bowings can be considered to fulfil a similar purpose to the added staccato dot. The changes of bow direction introduce more or less noticeable breaks producing units (of various length, associated with different kinds of bowstroke, bow-speed or pressure) that shape phrase accentuation in each passage. Bowings and articulation marks are annotated, in short, just as actors would scribble down clues on the page about how to link their lines; where to pause emphatically and how long for; or hints of the inflection they plan to use. ${ }^{67}$ An approach about which readers of Baillot's method seemed to require no convincing in 1803 , was in the early 1830 s given a more prominent place, possibly as it was seen to be undermined by the regime that over-detailed scores were enforcing.

A similarly detailed approach can be observed in Baillot's pencil fingerings. From a technical perspective, the entire first violin part of Boccherini Quintet $L$ 'Uccelliera is

\footnotetext{
65 'Les notes sont employée dans la musique comme les mots dans le discours; elles servent à construire une phrase, à former un sens [...] Mais les légères séparations, les silences de très courte durée, ne sont pas toujours indiqués par le compositeur, il faut donc que l'exécutant les introduise, lorsqu'il en voit la nécessite', Baillot, L'Art du violon, 163.

${ }^{66}$ See Doğantan-Dack, " "Phrasing - the Very Life of Music": Performing the Music and Nineteenth-Century Performance Theory', 8 .

${ }^{67}$ See for instance Mauduit-Larive, Cours de déclamation, vol. 2 part 1, 13.
} 
exceptionally accessible. There are no examples of passage-work requiring advance planning of which fingerings to use. It is all the more surprising, then, that Baillot marked nearly every shift of position for the left hand. This distinctive care in plotting combinations of fingerings, or where to use the fourth finger instead of an open string, reveals an ingenious use of the four strings to obtain a variegated tone in different sections. An example can be observed in the second movement of the quintet, the Allegretto entitled 'I Pastori e li Cacciatori' (Shepherds and Hunters). While copying a passage in the upper margin of his part, Baillot added fingerings, bowings, a general dynamic (piano), articulation (several staccato dots and an accent on the last note) and some grace notes, all of which are not specified in Boccherini's original notation (see musical examples $2 \mathrm{a}$ and $2 \mathrm{~b}$ ). ${ }^{68}$

\section{[INSERT MUSICAL EXAMPLE 2A AND 2B ABOUT HERE]}

Comparing the two notations of the same passage, it is likely that Baillot aimed to strengthen the 'horn fanfare' character of the melody. The decision to play the entire passage piano on the $\mathrm{G}$ string gestures towards a consistently opaque sound, separating this short episode from earlier and later sections in the movement. It is almost as if the scene suddenly shifts to a vast landscape with the sound of hunting horns from a distance. The staccato-articulated bowings that Baillot added to the dotted figures can also be read as giving further mordancy - in Lacépède's terms 'adding more paint' - to reinforce the hunt character of the episode. Boccherini's notation in this case well illustrates what Baillot called the clean page of 'music

\footnotetext{
${ }^{68}$ Baillot copied this passage from the first cello part to his, so that the piece could be performed as a quartet rather than a quintet. In this edition form which the ensemble played it, all sections that originally featured a solo assigned to the two cellos have been transposed and inserted in the first and second violin parts, possibly because a second cellist was not available for this performance. Such an approach was by no means unusual. Parisian publishers in the early nineteenth century printed chamber repertoire often indicating that one or more parts could be played at will by different instruments, especially if they read in the same clef. The Venier's edition of Boccherini quintets owned by Baillot states on the title page: 'les parties de Violoncelles sont facile pour l'exécution, et la seconde se pourra exécuter sur l'Alto ou un Basson'; Luigi Boccherini, Sei quintetti per due violini alto et due violoncelli concertanti Op. 13 (Paris, 1776); similarly Pleyel's much later edition reads: 'le $1^{\text {er }}$ Violoncelle peut être replacé par l'Alto-Violoncelle'; Luigi Boccherini, Six nouveaux quintetti pour deux violons, alto et deux violoncelles Op. 48 (Paris, 1813). A flexibility of a similar kind can be observed in how these players understood and handled the musical work as a multi-movement unity. Often only a selection of movements, or even just one movement, was performed. There is also evidence that, at times, the ensemble swapped movements between different Boccherini quintets. For instance, in Baillot's copy of Op. 37 n. $2,3^{\mathrm{e}}$ livraison (n. 53 in Baillot's own red numeration), he indicated that the minuet of this quintet be substituted with that of Op. 11 n. 6 L'Uccelliera; see Luigi Boccherini, Douze nouveau quintetti pour deux violons, deux violoncelles et alto Op. 37 (Paris, 1799), Paris, Bibliothèque nationale, Fonds Lainé, Carton 5, 1st violin, quintet n. 53 (G 308).
} 
of the past'. To execute the instructions in the score and nothing more would, we can imagine Baillot thinking, not suffice in making the 'hunters' stand out against the pastoral 'shepherds' of the previous section. The traces of the nuances Baillot devised for a particular performance show an effort to give life to these characters, inventing bold gestures, and differentiating them from one section to the next.

Baillot's fingerings, indicating to play the 'hunters' passage on the fourth string, can also be read in connection with his discussion of the tools available to violinists in their impersonations. In the Art du violon, Baillot included a new chapter on the characters of the four strings of the violin and their potential to evoke, for instance, the sound of other musical instruments:

Regardless of the timbre of the violin in general [...] there is a variety of timbre that each of its strings is capable of receiving from the performer, and by means of which [...] one can give to the violin the character of the oboe, that of the flute, horn, trumpet, harmonica and, with respect to its polyphonic aptitude, the character of the harp, of the piano and even that of the organ. ${ }^{69}$

[The fourth] string lends itself to the imitation of the horn [...]; it is sufficient to press rather strongly both the fingers and the bow to give to these sounds frankness and mordancy when the tempo is lively, and a great deal of fullness when the tempo is slow; and to bring the bow nearer the bridge so that the strength of the vibration renders more faithfully the noble and moving sounds of the horn. ${ }^{70}$

In the case of Boccherini 'I Pastori e li Cacciatori', then, a descriptive reference in the title (hunters), linked to a topical figuration in the piece (horn fanfare), was paired by Baillot in performance with an instrumental colour considered to imitate the horn timbre on the violin (G string). Yet these 'instrument-characters' that performers can impersonate are not understood in purely imitative terms. They become valuable tools especially when descriptive references are absent, such as in the incipit of Beethoven's Violin Concerto Op. 61, third movement, which is discussed by Baillot in the same chapter as an example of using the fourth string to 'imitate the horn timbre' (see musical example 3).

\section{[INSERT MUSICAL EXAMPLE 3 ABOUT HERE]}

\footnotetext{
69 'Indépendamment du timbre du Violon en général [...] il est une variété de timbre que chacune de ses cordes est susceptible de recevoir de l'exécutant, et au moyen de laquelle [...] on peut donner au Violon le caractère du Hautbois, celui de la Flûte, du Cor, de la Trompette, de l'Armonica, et, sous le rapport de son harmonie, le caractère de la Harpe, du Piano, et même de l'Orgue', Baillot, L'Art du violon, 140; emphasis mine.

70 'Ce corde se prêtent à l'imitation du Cor [...] il suffit d'appuyer assez fortement les doigts et l'archet pour donner à ces sons de la franchise et du mordant lorsque le mouvement est vif, et beaucoup de rondeur lorsque le mouvement est lent, et de rapprocher l'archet du chevalet pour que la force de vibration rende plus fidèlement les sons nobles et touchant du Cor', Baillot, L'Art du violon, 143.
} 
Rather than exemplifying the theme's character with a verbal narrative such as that provided by Momigny, Baillot used this instrument association to call for a sound that for him encapsulated a certain 'frankness and mordancy' in the attack and a 'noble' tone. Baillot's 'horn', in other words, is a nuance available for performers to put on their 'brush', whether or not a horn is part of the explicit 'picture' the composer might have had in mind. Baillot's approach to the musical text is, in a sense, to re-orchestrate his part, impersonating a number of characters and sound qualities in the piece.

Baillot's strategic use of different strings to give life to a variety of characters at times may also take on explicitly anthropomorphic traits. In the excerpt below from Luigi Cherubini's Fourth String Quartet in E (1834), Baillot's fingerings seem to emphasise the distinction between two constitutive elements of the passage by playing them on different strings: the energetic starting gesture (bar 1-3 after the repetition sign and bar 7 recalling it) on the G string (4. ${ }^{e}$ Corde); while its melodic continuation (bar 4, 9 and following) is on the $\mathrm{D}\left(3 .^{e}\right.$ Corde $) .{ }^{71}$

\section{[INSERT MUSICAL EXAMPLE 4 ABOUT HERE]}

Read through the lens of his Art du violon (which was close to completion at the time these pencil marks were added), Baillot's choices probably aimed to make the theme sound as if uttered by two voices: perhaps a tenor and a contralto, taking turns in a conversation staged within the first violin part. ${ }^{72}$ This kind of virtual splitting of the performer-actor is encouraged in Baillot's new chapter on 'the character of the four strings': his intention is to make the most of their individual expressive potential, comparing them to registers of the human voice:

\footnotetext{
${ }^{71}$ Luigi Cherubini, Quatuor Quatrième, autograph manuscript in parts, Paris, Bibliothèque nationale MS 360. In the present excerpt the use of 'loco' is typical of Baillot, always meaning 'go back to first position'.

${ }^{72}$ Cherubini drafted the quartet between September 1834 and February 1835, while Baillot was correcting the proof of the Art du violon in December 1834; see Pierre Baillot to Luigi Cherubini, 14 December 1834; quoted in Arthur Pougin, 'L. Cherubini: sa vie, ses œuvres, son rôle artistique', Le Ménestrel, 48/34 (23 July 1882), 266. This manuscript in parts of the quartet was used to try out different variants with the help of Baillot's ensemble. Baillot's pencil annotations are to be found also in sections that were deleted soon after the rehearsal; see Fabio Morabito, 'Il processo compositivo di Cherubini: il caso dei quartetti', in Sergio Miceli (ed.) Cherubini al "Cherubini” nel $250^{\circ}$ della nascita (Firenze, 2011), 167-188.
} 
The third string has the noble character and velvetiness of the contralto voice; it is particularly suited for the grandiose style and, without boasting the power and strength of the fourth string, it almost reaches its majesty.

The fourth string is the one that determines the supremacy of the violin; there are, on other instruments, sounds lower in pitch, but not with as much power. That is the tenor voice in all its beauty. [...] Its energy, its powerful voice alone is worth an entire instrument, and the deeper it reaches, the more it enhances the expression leading to the sublime. ${ }^{73}$

The passage from Cherubini's quartet could of course be played in first position, but the violinist's left hand would keep crossing the strings, mixing their distinctive sound qualities inconsequentially. Baillot's pencil annotations, by contrast, demonstrate the desire to gain a more refined control of the available colours, using them in avowedly dramatic fashion. Rather than one-off fingerings scattered here and there as a technical aid, in other words, these pencil marginalia are traces of a decisive plan to expose different musical 'voices', and even personalities, which Baillot aimed to embody while playing his part. ${ }^{74}$ What he was likely attempting here was to put together a 'musical plot', an imagined story or scene of his invention, not dissimilar in principle from that devised by Momigny for Mozart's K 421.

Producing annotated parts of this kind was a strategic part of playing with a sophistication of effect hardly possible if attempted on the hoof. The marginalia condensed the time spent in getting to know the piece's succession of characters and planning the means to perform them as if the audience was being shown different scenarios and personas. The same approach occurs throughout Baillot's library of annotated parts, regardless of how much the composer in question had attempted to notate performance indications. The above excerpt by Cherubini aptly illustrates the new regime of notation that Baillot saw as damaging the

\footnotetext{
73 'La troisième corde a le caractère noble et velouté de la voix de contralto; elle convient sourtout au style grandiose, et sans avoir la puissance et la force de la quatrième corde elle en a presque la majesté. [...] La quatrième corde est celle qui détermine l'empire du Violon; il y a, sur d'autres instrumens, des sons plus graves, mais on n'en trouve point qui aient autant d'autorité. C'est la voix de Tenor dans toute sa beauté. Son énergie, sa voix puissante vaut à elle seule tout un instrument, et plus cette voix est grave, plus elle favorise l'expression pour atteindre jusqu'au sublime', Baillot, L'Art du violon, 142-43.

${ }^{74}$ The idea of the performer as determining music's essential narrative as in the enactment of a plot has a longstanding tradition in scholarly literature. Traditional approaches have grounded such narratives in a scorebased structural analysis that the performer ought to carry out in preparation to the performance; see Wallace Berry, Musical Structure and Performance (New Heaven, 1989). At the opposite of Berry's model, there have been attempts to reject the priority of the score in scripting what players do, and to consider the act of performance as an enactment of identities (personae) rather than texts; see Philip Auslander, 'Music Personae', The Drama Review, 50/1 (2006), 101. My approach here is informed by that of Nicholas Cook, who sees no need for a hierarchy between playing 'something' or 'someone'. Performance is a multi-layered complex, and it is always possible 'to think at one more thing that is being performed, one more meaning that is emerging in the act of performance', Nicholas Cook, 'Bridging the Unbridgeable? Empirical Musicology and Interdisciplinary Performance Studies', in Nicholas Cook, Richard Pettengill (ed.), Taking It to the Bridge: Music as Performance (Ann Arbor, 2013), 83. See also Raymond Monelle, The Sense of Music: Semiotic Essays (Princeton, 2000), 160, 167-168.
} 
division of creative labour between composer and performer. Cherubini meticulously indicated slurs, staccati, and even marked a section to be played on the fourth string. Baillot's pencil entries, however, use Cherubini's notation as a starting point but then transcend it, to make it sound as if uttered by one or more fictional agents. ${ }^{75}$ In light of these annotated parts, then, Baillot's definition of the ideal performer as the one who 'senses in advance' the effects to use, may also be read as practical advice: not to leave such decisions to the spur of the moment helped ensure that the most essential feature of instrumental performance - a variety and liveness paper could not record or convey - was right there in the performer's translation.

\section{Playing with the composer's hands}

Juxtaposing advice from his treatises with evidence from his library of annotated parts, Baillot's image of the ideal performer closely resembles Momigny's description of the violinist as a 'consummate actor'. ${ }^{76}$ The task envisaged for the performer entails a speech-like sensitivity in delivering musical phrases and a talent for switching seamlessly between a variety of characters and expressions. Yet this versatility should not mark the performer disappear. Indeed, it is precisely the players' own inventiveness that shapes the experience of music as a series of moving portraits. But how was each composer given 'a particular physiognomy' - as Fétis put it in a review of Baillot's soirées - if performers were to use the same inventiveness in handling both recent and older repertoire ${ }^{77}$ How could Boccherini sound different from Beethoven if the players were expected to transcend the peculiarities of each composer's notation? Mary Hunter argues that, through the lens of methods published in the 1830s by Baillot and Johann Nepomuk Hummel, the act of performance aimed to

\footnotetext{
${ }^{75}$ Devising aspects of the accent often required coordination with the other players. Baillot's library of annotated parts offers evidence of moments when the ensemble rehearsed their gestures together before a performance. I discuss the element of planning that went into these concerts to explore how Baillot and his affiliates understood the ensemble interplay and internal hierarchies in my 'Rehearsing the Social: Beethoven's Late Quartets in Paris, 1827-29' (in preparation).

${ }^{76}$ Momigny, 'Soirées ou Séances Musicales', 374. See also November, 'Theater Piece and Cabinetstück', 1356.

77 'Personne ne sait comme lui [Baillot] donner à chaque auteur une physionomie particulière', François-Joseph Fétis, 'Soirées de quatuors et de quintettis [sic] de M. Baillot', La Revue Musicale, 2 (1828), 607-8.
} 
communicate to the listener what the composer had felt. This could be neither notated nor indicated; it had to be imagined. ${ }^{78}$ But how?

In a new section of his Art du violon of 1835, Baillot discusses composers' own fingerings as an effective aid to performers in imagining and impersonating musical identities.

If the composer has himself set the fingering, one should follow it as far as possible, to identify oneself with the style of the author, since fingering is one of the means [one uses] to characterise the style. [...]

[Even when they are not indicated] one will have to search for and finger according to the style, wellknown, of each composer. To perform their works in the spirit that dictated them, it is necessary to use similar means to those they have used. ${ }^{79}$

Performers are advised to practise styles of fingering different from their own, just as actors would master dialects or poses to step convincingly into a character. Appropriating someone else's style of playing could give the theatrical illusion of performing a piece 'in the spirit' of that person. Understood through the lens of theatricality, Baillot's recommendation to use composers' fingerings is hardly that to follow such instructions to the letter. Before being able to impersonate different composers, Baillot encourages performers to get to know them by mimicking their gestures. The prospect to reproduce someone else's movements prompts a kind of counterpoint between what one imagines the other would do and one's own moves. The encounter between the two musicians, in this sense, takes the shape of an imagined physical exchange, a conversation between bodies. The composer's fingering acts as an agent - a personality that comes alive in the mind and sensations of the performer - to which, with which or against which the performer reacts. ${ }^{80}$ Elisabeth Le Guin discusses in similar terms

\footnotetext{
${ }^{78}$ See Johann Nepomuk Hummel, Méthode complète théorique et pratique pour le pianoforte (Paris, [1838]), 438 originally published as Ausführliche theoretisch-practische Anweisung zum Pianoforte-Spiel (Vienna, 1828); see also Hunter, 'To Play as if from the Soul of the Composer', 367-68.

79 'Si le compositeur a fixé lui-même le doigter, on devra le suivre autant que possible, pour s'identifier avec le style de l'auteur, le doigter étant un des moyens qui servent à caractériser le style. [...] il faut chercher à doigter selon le genre, bien connu, de chacun auteur [...] Pour exécuter leurs ouvrages dans l'esprit qui les a dictés, il faut employer nécessairement des moyens semblables à ceux dont ils se sont servis'; Baillot, L'Art du violon, 146-47.

${ }^{80}$ See Nicholas Cook, Beyond the Score: Music as Performance (New York, 2013), 231, 249-287; and Carolyn Abbate, 'Music: Drastic or Gnostic?', Critical Inquiry, 30 (2004), 505-36. In Baillot's method, the suggestion to use a variety of fingering styles to impersonate different composers seems in the first place relevant in the case of music by other violinists. The chapter discusses excerpts by Viotti, Kreutzer and Rode, showing how each of them had a characteristic or preferred style of fingering (for instance by changing positions frequently, like Rode, or crossing strings, like Viotti); Baillot, L'Art du violon, 146-47. However, this theatrical use of fingering styles has broader applications, as in the example of the fingerings for Beethoven's Op. 127 discussed below. For a discussion of Haydn's fingerings in his string quartets as shaping the relationship between composer and performer, see Hunter, 'Haydn's string quartet fingerings: communications to performer and audience', 281301.
} 
her relationship with Boccherini. Her experience in playing his cello sonatas is described as searchingly physical but also 'somehow reciprocal'. Boccherini choreographs her bodily movements, while she acts out the connection between the parts of someone who cannot 'be there in the flesh. I have become not just his hands, but his binding agent, continuity, consciousness'. ${ }^{81}$

Traces of an attempted physical connection to impersonate the composer's style can be found in Baillot's annotated part of Beethoven Quartet Op. 127. Thanks to his acquaintance with Prince Nikolai Galitzin - Beethoven's dedicatee for this work and, also, a keen admirer of Baillot's soirées - Baillot received a set of parts bearing abundant handwritten annotations from an early Viennese performance of the quartet. ${ }^{82}$ It is uncertain which players had used the set, or in what circumstance, before it was sent to Baillot. Perhaps it belonged to one of the ensembles led by Ignaz Schuppanzigh, Joseph Böhm or Joseph Maysender, who performed the piece in the spring of 1825 . Or perhaps it had been used by a different group of musicians gathered in a more private setting at Prince Galitzin's residence. What is certain is that Baillot paid great attention to the handwritten fingerings he found in these parts. Eugène Sauzay, a student of Baillot soon to become the second violinist of the ensemble, recorded much later in his life:

We also rehearsed the late quartets by Beethoven that were sent to [Baillot] with fingerings that - alas! he had felt compelled to transcribe and observe. ${ }^{83}$

Further evidence of Baillot's interest comes from his chamber music library. The very part mentioned by Sauzay, a Schott edition that Baillot owned and into which he copied the Galitzin fingerings, is still preserved today. In the upper margin of the first page, Baillot specifies that 'fingerings have been marked according to those indicated on the parts of this

\footnotetext{
${ }^{81}$ Elisabeth Le Guin, Boccherini's Body: An Essay in Carnal Musicology (Berkeley, 2006), 14, 24.

${ }^{82}$ Prince Nikolai Galitzin attended Baillot's chamber soirées during the winter of 1821-1822, apparently remaining 'dazzled'. Baillot possibly received this annotated set of parts before the end of 1825 (the Viennese premiere of Op. 127 had taken place on 6 March); see Fauquet, Les sociétés de musique de chambre à Paris de la Restauration à $1870,98$.

83 'Nous avons essayé aussi les derniers quatuors de Beethoven qui lui étaient envoyés [...], avec les doigtés qu'il a cru hélas! devoir transcrire et respecter'; Brigitte François-Sappey, 'La vie musicale à Paris à travers les mémoires d'Eugène Sauzay (1809-1901)', Revue de musicologie, 60 (1974), 169. Sauzay wrote his memoirs retrospectively, more than sixty years after these rehearsals took place. Yet the negative resonance of his 'alas!' might hint to that the exercise in impersonations carried out by his teacher Baillot (trying different poses to give each composer a 'particular physiognomy') caused the rehearsals to drag beyond what the sixteen-year-old Sauzay was used to or wished for.
} 
quartet sent to me by prince Galitzin'. ${ }^{84}$ Baillot carefully transcribed the fingerings using ink, a medium which otherwise is almost never found in his parts (he generally used pencil or coloured pencil for his own annotations). Before essaying his own performance, Baillot probably saw in the Viennese performers' fingerings an opportunity to get acquainted with a yet unfamiliar musical character.

Against the backdrop of Baillot's ideology as laid out in his Art du violon, the Galitzin fingerings are, if you will, tactile traces of an 'acted' experience of Beethoven's Op. 127. For someone like Baillot interested in convincing musical impersonations, these annotations clothed the bare bones of music notation with the flesh and blood of real quartet players. These players were themselves impersonators who, in this case, were probably better acquainted with the composer's musical style than Baillot or his affiliates could claim. This was no little advantage in getting to grips with the idiom of Beethoven's late quartets. In a letter sent back to Prince Galitzin thanking him for the parts, Baillot depicts it as a sublimely remote realm, but also a somewhat arduous terrain to step onto:

Beethoven introduces you into a new world. You go across the wilderness, walk along precipices, the night catches you unprepared, you wake up and you are transported to ravishingly beautiful places, a paradise on earth all around you; the sun shines bright for you to contemplate the magnificence of nature..$^{85}$

Since its unfortunate Viennese première in March 1825, Beethoven’s Op. 127 had been deemed difficult to grasp at first sight. ${ }^{86}$ The range of dynamics was alarmingly wide with abrupt changes closely spaced together - somewhat evoking the 'wilderness' mentioned in Baillot's letter. Tempo shifts occurred often and precipitately - akin to when 'the night catches you unprepared'. The variety of keys was problematic for intonation and a kaleidoscopic succession of textures made ensemble playing hard to coordinate - something

\footnotetext{
84 'Le doigter a été marqué d'après celui indiqué sur les copies des partitions de ce quatuor qui m'ont été envoyé par le prince Nicolas de Galitzin', Louis [sic] van Beethoven, $15^{e}$ Quatuor pour deux Violons, Alto et Violoncelle, Composé et dédié à son Altesse Monseigneur le Prince Nicolas de Galitzin, Euvre 127 (Paris: Schott, [1827]), Paris, Bibliothèque nationale MS VMA 3900 (4) 1st violin, 2. Baillot copied the Viennese fingerings and annotations only on his own part, that of first violin.

85 'Beethoven vous introduit dans un nouveau monde. Vous traversez des régions sauvages, vous longez des précipices, la nuit vous surprend, vous vous réveillez et vous êtes transportés dans des sites ravissants; un paradis terrestre vous entoure, le soleil luit radieux pour vous faire contempler les magnificences de la nature'; Pierre Baillot to Nikolai Galitzin quoted in Wilhelm von Lenz, Beethoven et ses trois styles (Paris, 1855), 2: 5-7. Baillot's letter resonates with E.T.A. Hoffmann's famous review of Beethoven's Fifth Symphony, especially in the passage where this music is said 'to open an unknown realm, a world quite separate'; Allgemeine musikalische Zeitung, 12 (4 July 1810), col. 631; and Loughridge, Haydn's Sunrise, Beethoven's Shadow, 4-6, 22-24.

${ }^{86}$ Gingerich, 'Ignaz Schuppanzigh and Beethoven’s Late Quartets', 470.
} 
comparable to 'walking along precipices'. Before venturing to create nuances and characterise a style with which he was not yet familiar, Baillot turned to a stylised depiction of the Viennese performers' movements. In retracing them, there was a potential to gain a bodily sensation of the composer's style as impersonated by players who had already sailed through the piece and come to terms with its expressive qualities. A new and distant world, such as that evoked in Baillot's letter, would suddenly come within hand's reach.

Baillot's handling of the Viennese fingerings demonstrates a desire to reach beyond the notation and straight across to the composer's feelings as they were imagined by others. As Mary Hunter has argued, Baillot is essentially aligned with Hummel (1828) and Georg Friedrich Hegel (1818-29) in envisaging this kind of 'intuitive grasp', which in the case of Baillot is less to do with inferring how composers would have had their music performed, and more with getting to know their distinctive character and the expressive qualities of their music. ${ }^{87}$ Once experienced this kind of connection, the performer was expected to use the palette of available instrumental colours and effects to give to each composer in the programme a distinctive sound. That Baillot championed this protected creative space for performers to work without the composers' guidance can be observed also in his ensemble's relationships with the Paris-based composers whose works featured in the series. These artists regularly attended the concerts, yet it appears they were deliberately kept at an arm's length from the rehearsals. In a letter from 1834 to Cherubini, for instance, Baillot asked his friend and former composition teacher to let the players rehearse by themselves:

We intend to read your second [quartet], in C, next Saturday and we hope to see you there, with Mrs. Cherubini and the good Salvador [i.e. Cherubini's son]. There is no need for you to take care of our rehearsals; we will do more freely without you. Your presence intimidates us, since we sense all the harm that we are doing to you with our criminal errors. But once the piece is well understood and properly rehearsed, whether you are present or absent, we will see you at the end of each note, or rather sense your presence in the heart and so indulge ourselves in all the feelings that your admirable works inspire. Please continue to enrich us with beautiful things, to complete our repertoire, which started with Haydn and Mozart and must continue with you and Beethoven closing the course of this beautiful musical century. [...] We will never render your inspirations so well as they should; but believe that everything coming out of your soul cannot be rendered by us if not with the deepest sense of respect, love and gratitude..$^{88}$

\footnotetext{
${ }^{87}$ Hunter distinguishes this early Romantic ideology of performance from earlier accounts, such as those by Leopold Mozart (1756), Jean-Jacques Rousseau (1768) or J. A. P. Schulz (1774) that tended rather to advise performers to use experience and study to decode correctly musical affects and expressions. Much in line with my discussion of the marginalia, Hunter remarks that this aspect is still relevant in Baillot's conception but alongside a less positivistic and more down-to-the-individual-performer choice of how to nuance and bring to life in performance different authors, works or sections therein; see Hunter, 'To Play as if from the Soul of the Composer', 363-9.

88 'Nous comptons lire votre second, en ut, samedi prochain, et nous espérons bien vous y voir, ainsi que Madame Cherubini et le bon Salvador. Ne vous occupez point de notre répétition; nous la ferons plus librement sans vous. Votre présence nous intimide, parce que nous sentons tout le mal que nous vous faisons par l'effet de
} 
Baillot had, in other occasions, lent his ensemble to help Cherubini decide between variants, letting him modify sections of his quartets directly on their music stands. ${ }^{89}$ It is possible, then, that in this case he aimed to ensure Cherubini would not show up with second thoughts or more variants to try. Even so, Baillot's pre-emptive containment of Cherubini's compositional process highlights how the different creative agents involved were supposed to behave in the context of these chamber music soirées.

The depiction of the players sensing Cherubini behind every note evokes a spiritual link of the kind that Baillot aimed to build with Beethoven via the Galitzin fingerings. The 'Cherubini' the ensemble felt present is clearly not the historical individual, but rather 'the author': a character the players postulated and produced in interacting with the score. ${ }^{90}$ Cherubini-author, as Baillot puts it, is made of those feelings that the works by Cherubinireal-person inspire. In this perspective, Baillot's letter can be read as trying to put each 'Cherubini' in his place. His friend should continue to write quartets and gain a place among the genre's musical heroes. He is neither supposed, nor able, to micromanage the players' moves or nuances, as he might have conceived them in writing the piece. Baillot is clear about the feasibility of such a prospect: 'we will never accomplish that'. Yet Cherubini-realperson should fear not, as Baillot and his ensemble had a long and intimate relationship with Cherubini-author, allowing them to convincingly impersonate this character for the audience. At the opposite of the situation prompted by Cherubini's music, which these players had already 'in their hearts', Baillot aimed to familiarise himself via other musicians' gestures with the feelings prompted by Op. 127; that, is with 'Beethoven-the-author'. The Galitzin

\footnotetext{
nos criminelles erreurs; mais une fois le morceau bien compris et bien répété, que vous soyez présent ou absent, nous vous voyons au bout de chaque note, ou plutôt nous sentons votre présence dans le cœur et nous nous livrons alors à tous les sentiments qu'inspirent vos admirables ouvrages. Continuez, je vous en prie, à nous enrichir de belles choses, à compléter notre répertoire, que nous avons commencé avec Haydn et Mozart, et que nous devons poursuivre avec vous et Beethoven, qui fermera la marche de ce beau siècle musical. Nous ne rendrons jamais vos inspirations aussi bien qu'il le faudrait; mais croyez que rien de ce qui sort de votre âme ne peut être rendu par nous qu'avec le sentiment le plus profond de respect, d'amour et de reconnaissance'. Pierre Baillot to Luigi Cherubini, 14 December 1834; quoted in Pougin, 'L. Cherubini: sa vie, ses œuvres, son rôle artistique', 266.

${ }^{89}$ In his memoirs, Sauzay laments that 'we would run [Cherubini's quartets through and again] in the Director's office, where the overly irritable author had written himself, in his trembling hand, the parts of the quartet that he had filled up with variants, putting a strain on our patience'; François-Sappey, 'La vie musicale à Paris à travers les mémoires d'Eugène Sauzay', 168. Sauzay's account has a unique material counterpart in the manuscript parts of Cherubini's fourth string quartet discussed above; see Paris, Bibliothèque nationale MS 360 and Morabito, 'Il processo compositivo di Cherubini: il caso dei quartetti', 167-188.

${ }^{90}$ See Michel Foucault, 'What is an author', in Paul Rabinow (ed.), The Foucault Reader (New York, 1984), 101-20; Alexander Nehemas, 'What an Author Is', The Journal of Philosophy, 83 (1986), 686.
} 
fingerings copied in ink, however, did not transform Baillot into a puppet. From his part (see musical example 5), it is evident how he changed them at will, adding his own with blue or normal pencil. ${ }^{91}$ Once he had grasped the character, he moved on - business as usual - to invent the nuances characterising his own performance. Baillot's cautious encounter with the unfamiliar style of Beethoven's late quartets, in short, did not alter his attitude to the musical text, his understanding of what it meant to perform music effectively.

\section{[INSERT MUSICAL EXAMPLE 5 ABOUT HERE]}

The increased specialisation of composers' and performers' tasks in the early nineteenthcentury has been often explained through the lens of Beethoven's biography. As the century's prototype composer would no longer perform his music, so the story goes, his scores became equipped to choreograph countless musicians in doing the same moves. That of Pierre Baillot, in this respect, is a counter-narrative told from the perspective of - and about - a new prototype of professional performer. His pedagogical reflections and marginalia recast the alleged transformation of scores into complete musical artefact as a misunderstanding. What composers notated in ever greater detail was a partial attempt to compensate for a new kind of performer required in contemporary concert culture: a consummate impersonator, able to switch at once between a wide variety of expressions and nuances, to the point of making instrumental music sound as if uttered by different characters, or depicting their movements through different scenarios and feelings. Listening to the voice of the score, twentieth-century musicology and its vision of scholarly editions has rather tended to give normative status to instructions that accomplished performers in the early nineteenth century were, in fact, advised to transcend. Our familiar twentieth-first-century grumble at different works in the same concert (or different recordings of the same piece) sounding almost identical, is a risk that Baillot saw coming in the early decades of the nineteenth century. His response to fight the automatization of performance and flattening of performing styles is still profoundly ingrained in today's institutional training for professional musicians. Baillot championed the

\footnotetext{
${ }^{91}$ The two systems of annotations at times implement each other, but often they overlap and an ink-fingering gets replaced by a blue one. In example 5, in the seventh staff Baillot added in blue pencil 'restez [à la position]' to remain in the same position of the previous ink-fingering (2) on the third note of the second bar. Two bars later he crossed off the ' 2 ' in ink (implying third position) and added in blue ' 4 ' and 'loco', both meaning to play the passage in first position.
} 
performance of earlier repertoires - with fewer performing and expressive indications - as beneficial for performers to avoid losing their creative approach in inventing nuances when handling modern, more detailed scores. Additionally, in his pedagogical vision and practice as professional, the chamber music concert became a safe haven for performers to work on refining their expressive palette, rhetorical pauses, phrasing and instrumental colours in impersonating a variety of characters. The ambition to make each composer and number in the programme sound different (particularly exposed in a concert format in which performers do not alternate) is what made commentators perceive Baillot's soirées as a model for modern instrumentalists and their performances across genres. The marginalia form the ensemble's library reveal how Baillot meant accomplished performers to avoid falling victim of the new regime of musical notation, and continue to allure the listeners' mind into a theatre-like spectacle of imagined characters and their stories. 